\title{
Article \\ Object Analysis and 3D Spatial Modelling for Uniform Natural Resources in China
}

\author{
Shen Ying ${ }^{1, *} \mathbb{C}$, Chengpeng $\mathrm{Li}^{1}{ }^{1}$, Naibin Chen ${ }^{1}$, Yizhen Jia ${ }^{1}$, Renzhong Guo ${ }^{2}$ and Lin $\mathrm{Li}^{1}$ \\ 1 School of Resource and Environmental Sciences, Wuhan University, Wuhan 430072, China; \\ lichengpeng@whu.edu.cn (C.L.); chen_nb@whu.edu.cn (N.C.); jiayizhen@whu.edu.cn (Y.J.); \\ Linli@whu.edu.cn (L.L.) \\ 2 Research Institute for Smart City, Shenzhen University, Shenzhen 518060, China; guorz@szu.edu.cn \\ * Correspondence: shy@whu.edu.cn
}

check for updates

Citation: Ying, S.; Li, C.; Chen, N.; Jia, Y.; Guo, R.; Li, L. Object Analysis and 3D Spatial Modelling for Uniform Natural Resources in China. Land 2021, 10, 1154. https://doi.org/ 10.3390/land10111154

Academic Editor: Francisco Manzano Agugliaro

Received: 28 September 2021

Accepted: 25 October 2021

Published: 29 October 2021

Publisher's Note: MDPI stays neutral with regard to jurisdictional claims in published maps and institutional affiliations.

Copyright: (c) 2021 by the authors. Licensee MDPI, Basel, Switzerland. This article is an open access article distributed under the terms and conditions of the Creative Commons Attribution (CC BY) license (https:// creativecommons.org/licenses/by/ $4.0 /)$.

\begin{abstract}
Natural resource management has entered a new stage in 2018 in the People's Republic of China (China) marked by the establishment of the Ministry of Natural Resources of China (MNRPRC). More functions and responsibilities are integrated in the MNRPRC to build a uniform management system for full natural resource features in China with the aim of implementing uniform spatial planning and regulation, management, use and control, surveying, and registration for full natural resources. This paper first provides a detailed analysis regarding full natural resources with the perspectives of spatial forms and rights, restrictions, and responsibilities (RRRs); then, the modelling foundation of the "uniform" concept in natural resource registration is reconsidered. Lastly, we put forward a basic conceptual model for the uniform registration of full natural resources based on LADM (Land Administration Domain Model).
\end{abstract}

Keywords: uniform natural resource registration; 3D cadastre; modeling; land; building; property unit; right

\section{Introduction}

In 2018, China carried out a reform that combines several departments related to natural resources into a comprehensive department called the Ministry of Natural Resources of the People's Republic of China (MNRPRC). The MNRPRC aims to integrate the responsibilities of the previous Ministry of Land and Resources of the People's Republic of China (MLRPRC), the Ministry of Housing and Urban-Rural Development of the Republic of China (MHURDPRC), the Ministry of Water Resources of the People's Republic of China (MWRPRC), the Ministry of Agriculture of the People's Republic of China (MAPRC), the State Forestry Administration of the People's Republic of China (SFAPRC), the State Oceanic Administration of the People's Republic of China (SOAPRC) and the State Bureau of Surveying, Mapping and Geographic Information (SBSMGI) to build a uniform management system for full natural resource features in China. This process indicates that the management of various types of natural resources, including land resources, building/construction resources, mineral resources, forest resources, grassland resources, water resources, farmland resources, ocean resources, etc., is no longer individually handled and managed. Traditionally, the different types natural resources are managed separately, and now, the four unification of natural resources (FUONR) that was advocated by MNRPRC accounts for the following purposes and the responsibilities of the MNRPRC:

- Uniform management of the natural resource assets owned by the nation;

- Uniform use and control of national space and ecological conservation and restoration;

- Uniform survey and registration of full natural resources;

- Uniform multiple rules and regulations relevant to national land space.

In the FUONR, land, as the basic natural resource, which bears other natural resources, can convey the characteristics of uniqueness and absoluteness, and the core of 
the FUONR is the uniform relationship of land space, numerous natural resources, and relevant stakeholders with uniform geometric description, thereby forming a uniform representation and management system. Traditional land-administration systems that are based on two-dimensional representations cannot precisely represent 3D objects in the real world and handle intricate 3D natural resource spatial problems [1]. Therefore, related theories, regulations and data models of land and properties related to 3D resources have become a huge challenge that has attracted attention around the world [2,3].

The Interim Regulation on Real-Estate Registration (IRRER) issued in 2015 and the Property Law of the People's Republic of China (PLPRC) issued in 2007, now are replaced by Civil Code of the People's Republic of China in 2021, stated that the use rights of construction land could be created separately, either on the surface of the land or above/under the surface, and that newly established land could not damage the rights/benefits of real-estate objects [4] that comprise natural resources. Therefore, land-related contents, especially in the context of rights legislation in China, have been extended to the vertical direction in a 3D space, which provides a legal basis to create, register, and administrate 3D natural resources.

The common and fundamental principle is that full natural resource objects exist in a geographical space. The basis of uniform natural resources is to take a unified 3D space for full natural resources, through which natural resources can be consistently described, represented and modelled, and uniform management and registration can be supported [5] Some developed cities in China, such as Shenzhen, have already established independent land-utilization projects that set the rights on, above, or under the Earth's surface [6] with a corresponding 3D geographic space. However, most existing land and land-related natural resource management systems are based on 2D and have their own geographic references, which leads to neither support for the modelling of different geographic objects nor the description and management of immovable 3D properties. Thus, object analysis and 3D space modelling of full natural resources for the FUONR in China become an urgent task. This paper investigated related works (Section 2) in China and proposes a natural resource unification model (NRUM, Section 5) fitting for China's national conditions under the actual requirements of urgent progress during the FUONR (Section 3) to implement uniform natural resources management. The proposed model is based on an elaborate analysis of the spatial forms of Chinese natural resources (Section 4) and the definition of a feasible unit of spatial property (Section 5).

\section{Related Works}

Separate natural resource management programs, including house property and cadastres, have been conducted in many countries, but this type of management mode has many drawbacks in terms of maintaining consistency between different natural resource objects and properties. Before the IRRER was published, Chinese scholars performed a thorough analysis of the temporal situations, factors, drawbacks, rules and registration specifications regarding real estate from both theoretical and practical perspectives $[7,8]$. Lin presented a 3D conceptual model that integrates housing properties with cadastral information based on the land usufruct [9]. Traditional cadastral management is based on 2D parcels, while natural resource objects typically exhibit 3D shapes and should be handled in 3D space in correspondence to the real world, which makes the definition and representation of natural resources units (we use the term "natural resource unit" hereafter) very important. Rights, responsibilities, and restrictions (RRRs) are the core of land administration [10]; thus, natural resource unit as an administrative unit could be defined and divided by their rights [5]. In particular, 3D natural resource management is based on an inexorable trend [6,11], and some scholars have presented a basic framework for converting 2D data models to 3D data models after analysing and summarizing the characteristics of spatial objects using existing 2D cadastral data; 3D cadastral data models have also been compared based on object-oriented 3D models [12,13]. Other efforts have included different 3D cadastral cases in different countries [14-17], the automatic generation of 3D natural 
resource objects [6,18], the design of full 3D cadastral systems [2,14], and the modelling and visualization of 3D parcels [19-21]. After the IRRER was implemented, the 3D modelling of the ownership structure of condominium units combining the representation of LADM and CityGML in China was introduced [22], and a uniform registration model of natural resources interprets the IRRER in China with great detail [23].

The land administration domain model (LADM) [2] provides an extensible basis for the development and refinement of efficient land-administration systems and creates a standardized information service among different countries or apartments, and many scholars have applied the LADM to land management in their country. Some countries (e.g., Poland and Netherland) have already established real-estate registration systems based on the LADM [24], and others have begun to explore the relationship between this model and the national land policies of their countries [11,16,25-27]. In China, the basic goal of uniform registration is to unify registration authorities, institutions, information platforms and books. A LADM-based model that is suitable for the recombination of land and building data has been presented [28], and a prototype system has been developed to verify this model's feasibility [29]. The new revision of LADM consists of new parts: land registration, marine space georegulation, valuation information, and spatial planning information that would involve all the natural resource and man-made constructions to adapt the integration of land, natural resources and property.

Obviously, studies focused on real estate and land that contribute to natural resources and existing land management systems, which are still the main method to manage land, cannot satisfy the current requirements of uniform natural resource management. The requirements to implement an NRUM have already become a reality because of the amendment of relevant laws and regulations and the requirements of Chinese national conditions. At the same time, techniques for the management and measurements of 3D spaces have been widely developed, which provide a solid technical basis to construct an NRUM. Thus, a 3D NRUM must be introduced as soon as possible.

\section{Requirements for NRUM}

\subsection{Official Evolution Background}

Before 2018, different ministries were responsible for the management of various objects of natural resources (Table 1). For example, city land and rural land/farmland were charged by the Ministry of Land and Resources of the People's Republic of China (MLRPRC) and the Ministry of Agriculture of the People's Republic of China (MAPRC), respectively, while housing/buildings were managed by the Ministry of Housing and Urban-Rural Development of the People's Republic of China (MOHURD). The rules and regulations of the geographic representation of the objects that were formulated by these relevant ministries are not consistent; for example, the categories of land cover and land use are different in previous three organizations.

Table 1. Natural resource management institutions before 2018.

\begin{tabular}{cc}
\hline Managed Objects & Institution \\
\hline Housing/building & Ministry of Housing and Urban-Rural Development of the People's Republic \\
of China (MOHURD) \\
Land registrations & Ministry of Land and Resources of the People's Republic of China (MLRPRC) \\
Land cadastral data & Ministry of Agriculture of the People's Republic of China (MAPRC) \\
Farmland & State Forestry Administration of the People's Republic of China \\
Forest land/grassland & Ministry of Agriculture, Fisheries Bureau of the People's Republic of China \\
Water area & State Oceanic Administration of the People's Republic of China \\
Sea area & a
\end{tabular}

Because full natural resources, including urban land, farmland/agriculture land, forest land, grassland, and water, and the attached buildings and construction co-exist in the same geographic space and are integrated, the best way to handle them is to place them all under the same ministry, which can help maintain consistency and enhance the efficiency of government management. Therefore, the Chinese government had carried out major 
government reforms and established the MNRPRC on 14 March 2018, to integrate the management, use, control, investigation, registration and legislation responsibilities for natural resources including land, minerals, waters, grasslands, and forests, with the goal of unifying authorities and information platforms and to further accelerate the efficiency of uniform investigation, supervision, and registration management of natural resources.

According to the MNRPRC's comprehensive rights and duties regarding natural resources, a newly process of managing natural resources should be established. Since 1984, the MLRPRC have presided over the National Land Survey twice and a National Geographical Conditions Survey, and the third National Land Space Survey (renamed from National Land Survey officially) has been scheduled by the MNRPRC from 2018 to 2020. Thus, a uniform system of natural resources should be developed while taking the surveying and mapping geographic information as the entry point and the basis to construct a uniform natural resource geographical space, a semantic system, and service processes.

\subsection{Uniform Registration of Real-Estate}

Natural resource models are the key to bridge natural resource objects in the real world and their representations in a digital environment. In particular, such a model must express a common understanding of natural resource objects in the real world [12]. The locations and occupations of 3D volumetric spaces are the most essential characteristics of natural resources and are the key to distinguishing and managing natural resource objects [30]. Generally, land and its attachments in China are handled under two scenarios: urban environments and rural environments. Collective land, farmland, and homestead land are located in rural environments, while construction land is located in urban environments.

According to the IRRER, the term "real estate" refers to various land areas, sea areas, construction projects, buildings/houses, forests and trees, and other appertaining properties. In detail, the rights that are involved in real estate registration include the following ten types:

(1) Collective land ownership

(2) Ownership of constructions and structures such as buildings

(3) Ownership of forests and woods

(4) Rights to the contracted management of farmland, forest land and grassland

(5) Use rights of construction land

(6) Use rights of homestead land

(7) Use rights of water/sea

(8) Easement

(9) Mortgage rights

(10) Other rights that require registration according to relevant laws

According to the list of the relevant ministries focused on natural resources in the past (Table 1), after the establishment of the new Ministry of Natural Resources, the following natural resources management and utilization are classified as uniform: land (collective land, construction land and homestead land), mines, water, oceans, forests, grasslands, buildings, etc. We should be aware that buildings/constructions and land are inseparable and man-made buildings/constructions is also involved in the uniform registration.

\subsection{Unit Representation from 2D Land to 3D Geospace}

Land is special in the uniform system because it is not only a natural resource, but also a carrier of other natural resources. In China, previous management systems of forest, farmland and grassland were separate and isolated from each other, and they used 2D shapes to describe and represent geographic objects boundary and shapes. However, some complex requirements, such as mining, geology, water projects, urban construction, and cadastre management promote the introduction of 3D representation. Land typically handled in a 2D environment with many 2D units and geospace is generally perceived in a 3D environment with 3D units (Figure 1). To support uniform natural resource management, land with its carrier characteristics under the demand of unification of 
geographical space must transform from 2D to 3D form. Meanwhile, the changes from 2D to 3D land space provides for the full development and planning of 3D space, and a detail analysis of all natural resources is described in Section 4.
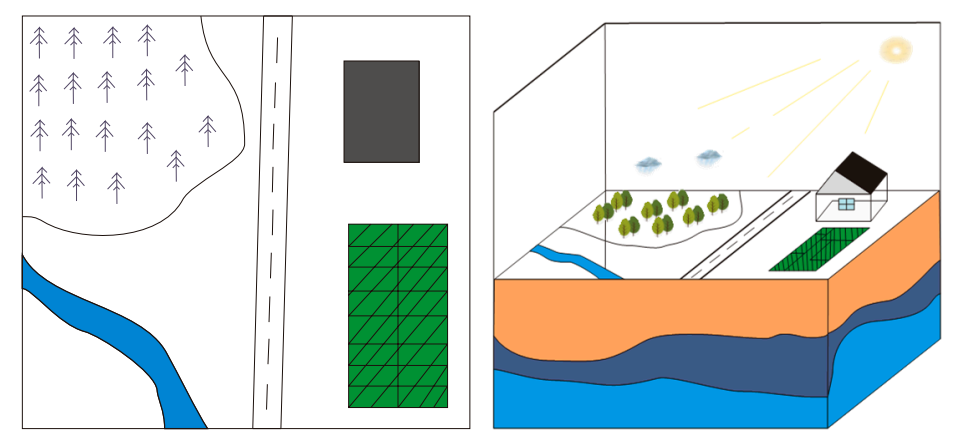

Figure 1. Different presentations of land and land space.

\subsection{Variety from Single to Full Features}

In the past, all natural resource features were isolated to the field level such that the spatial relationships of different features that exist in a mutual space were missed. Thus, the evolution of full natural resources could not be described because of the absence of constructing the interrelationship among them. Therefore, the concept of "full features of natural resources" is proposed to match the real natural resource circumstance. However, the "full" is just an ideographic expression that means geographic features are taken into account as much as possible. For example, in terms of land, a desertified grassland is often formed during a slow and long process and evolved from several natural resources, such as sand, grass, and land with complicated and mixed wind weathering erosion. In addition, the construction synthesis of metro in the vertical has an effect on the Earth's surface and the underground minerals and geologic body.

\section{Object Analyses of NRUM}

The main function of a uniform natural resources model is to confirm the spatial position of natural resource objects and describe the ownership, use rights, and other rights or obligations that are associated with natural resource objects. Users can consistently locate and represent the entities of natural resource objects within a uniform geographic space to ensure that consistent rights are imposed. Natural resource objects occupy their own 3D space without overlap (Figure 2). The basic purpose of natural resources registration is rights verification. The essential precondition of market transactions is the unambiguous demarcation of the rightful position of natural resources. Deep analysis regarding the spatial forms of natural resource objects is the basis to understand the spatial occupation and locations of natural resource objects because of their complexity. According to the spatial morphology of land and building shapes, the spatial forms of property units can be categorized into three different types: open, semi-delimited, and fully delimited $[6,23]$. The requirements for an NRUM, which were described in Section 3, indicate ten types of property rights for various property objects, which are described in detail in this section. 


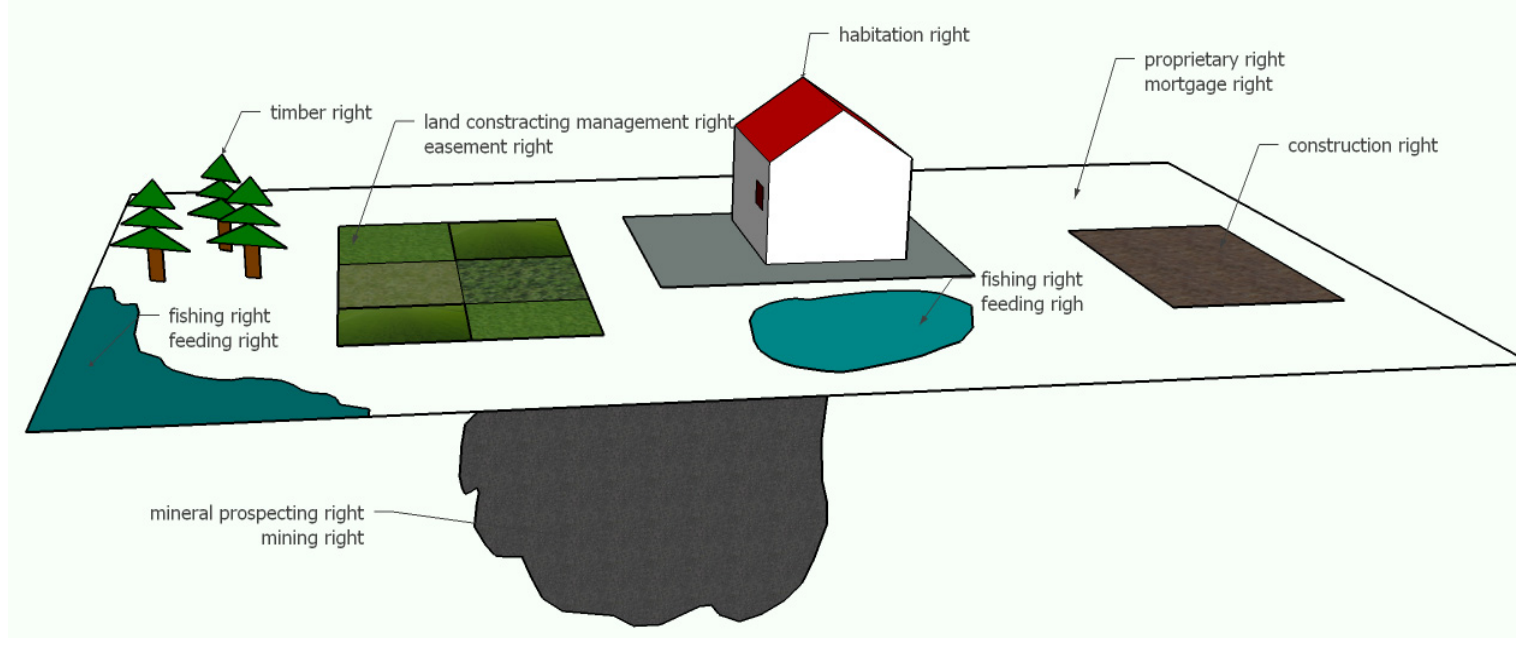

Figure 2. Relationship between spatial objects and rights.

The information within an NRUM should include (1) attributes, such as a unique identification number, the type of the natural resources, its location, boundaries, 2D spatial boundaries, 3D delimitation, acreage, approved usages etc., and (2) rights information, such as the owner, type, contents, source, term, change and other natural resources rights that are common to full natural resource objects. Other disparate contents of natural resources should also be contained in the uniform according to the unique spatial locations and characteristics of the natural resource objects.

\subsection{Collective Land}

Collective land is located in rural environments. The ownership of collective land belongs to farmer collectives. Housing sites, privately farmed plots of cropland, and hilly land are owned by the collectives. Collective land is physically located on the Earth's surface in 3D space with an up and down surface (Figure 3); however, such land is officially typically represented by flat 2D parcels (Figure 4). These parcel certificates, which exhibit 2D pictorial forms, describe only the location (coordinates) and boundaries of the 2D parcels and cannot fit or provide the precise details of various 3D landforms. For example, the hilly lands in Figure 3 have different surfaces land with different areas than the flat 2D horizontal projective areas.

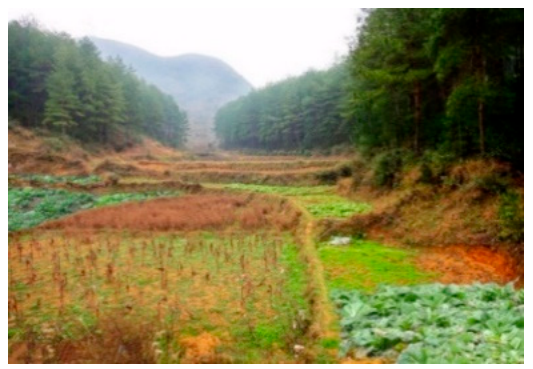

(a)

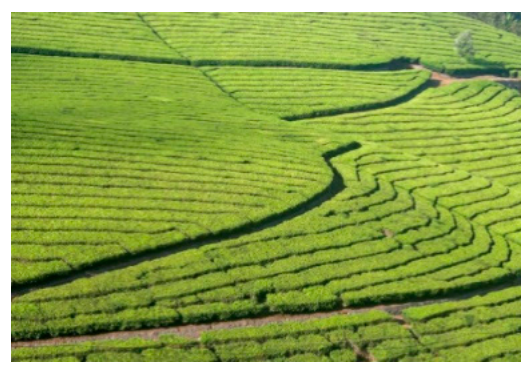

(b)

Figure 3. Cont. 


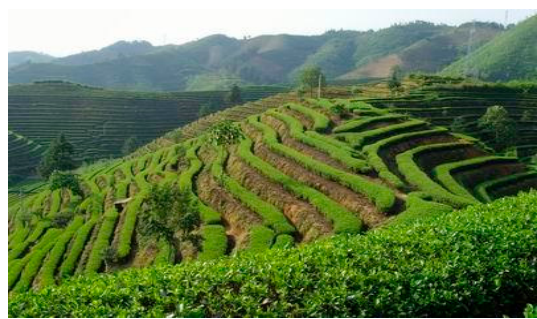

(c)

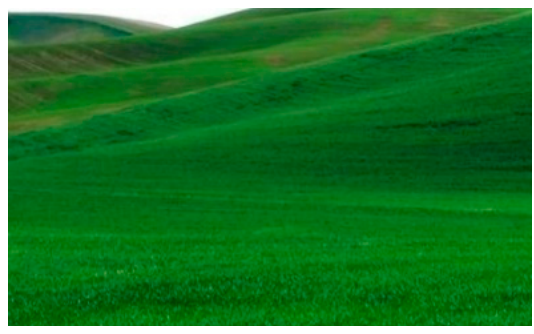

(d)

Figure 3. Typical spatial forms of collective lands: privately farmed plots of cropland $(\mathbf{a}, \mathbf{b})$; privately farmed plots of hilly land (c,d).
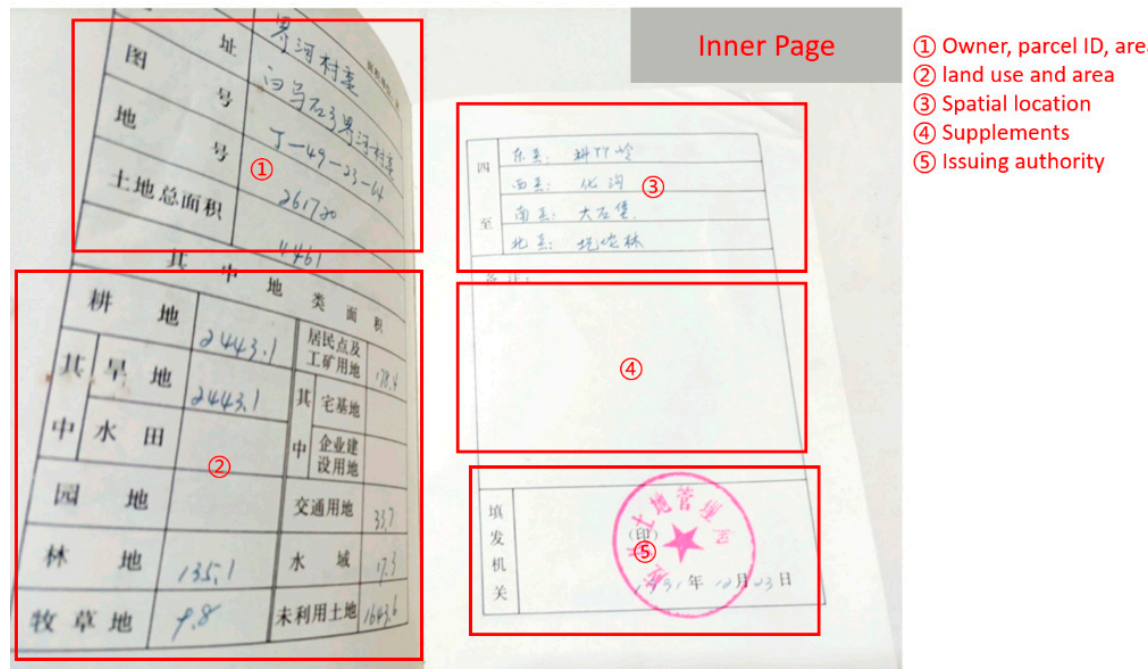

Figure 4. Certificate of collective land ownership (source: https:/ / pic17.997788.com/_pic_search/00 /27/06/15/27061537b.jpg, accessed on 26 October 2021).

Although the spatial forms of most collective lands are irregular, the ownership of such properties belongs to the farmer collectives. The holder of this natural resource should be registered as the collective that owns this land, and each farmer only possess the use right to cultivate and farm. Collective land can be regarded as "open type" properties represented by a 2D horizontal projective plane.

\subsection{Buildings and Construction Projects}

The difference between buildings and construction projects is that the construction projects (i.e., water towers, ponds, biogas digesters) cannot provide accommodations and living functions, while buildings often do.

A certificate of building ownership in an urban area is shown in Figure 5, which lists basic textual information for the building. However, this certificate does not describe the property with a matching land-parcel map. Furthermore, the spatial forms of realistic urban buildings are more complex; 2D parcel maps cannot completely illustrate their shapes and spatial information.

Most construction projects in urban areas can be considered as "open type" properties, because their spatial forms are regular and their property ownership is consistent; these 3D entities can be represented by a horizontal 2D projective plane with certain height ranges.

Buildings in urban areas should be considered "fully delimited type" properties because of specific spatial constraints during the development and utilization of underground spaces. From the perspective of spatial-rights management, buildings can be divided into two types: regular buildings and irregular buildings. Condominiums (Figure 6a) are typical regular buildings and can be defined as "fully delimited type" properties, because the 
property rights are owned by different individuals within a single construction (residential building). However, the property rights of underground portions may be separate from the property rights of aboveground portions, as demonstrated in Figure 6b. These distinctions should be clarified during registration. Irregular buildings (Figure $6 c, d$ ) can be regarded as "fully delimited type" properties, because the property rights of these buildings may intersect and overlap with each other in vertical space. However, the complicated design of their aboveground portions makes an NRUM more difficult, as illustrated in Figure $6 \mathrm{c}, \mathrm{d}$. Therefore, more mature technologies are required to build 3D property units for irregular buildings.

\begin{tabular}{|c|c|}
\hline 权利人 (1) & 张三 \\
\hline 共有情况 (2) & 房屋单独所有 \\
\hline 坐落 (3) & 安徽省 $\mathrm{XX}$ 市 $\mathrm{XX}$ 小区 1 号楼 602 \\
\hline 不动产单元(4) & $340 X X X 002002$ GB00151 F00010002 \\
\hline 权利类型(5) & 国有建设用地使用权/ 房屋所有权 \\
\hline 权利性质(6) & 出让/商品房 \\
\hline 用途 (7) & 城镇住宅用地/住宅 \\
\hline 面积 (8) & 共有宗地面积 5980.7 平方米 / 房屋建筑面积 148.15 平方米 \\
\hline 使用期限 (9) & 国有建设用地使用权 2010 年 10 月 24 起 2080 年 10 月 23 日止 \\
\hline 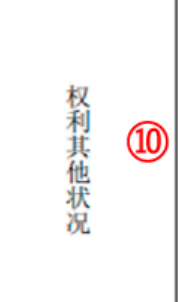 & $\begin{array}{l}\text { 分推土地使用权面积: } 15.93 \text { 平方米 } \\
\text { 房屋结构: 钢筋混㠜土结构 } \\
\text { 专有建筑面积: } 117.31 \text { 平方米, 分嶊建筑面积: } 30.87 \text { 平方米 } \\
\text { 房屋总层数: } 12 \text { 层, 所在层: 第 } 6 \text { 层 } \\
\text { 房屋竣工时间: } 2014 \text { 年 } 01 \text { 月 } 01 \text { 日 }\end{array}$ \\
\hline
\end{tabular}

(1) Right holder

(2) Condo or detached

(3) Address

(4) Code

(5) Right type

(6) Right acquisition

(7) Land-use type

(8) Area

(9) Life span

(10) Supplements

Figure 5. Ownership certificate of an estate building (source: http://news.focus.cn/zh/2015-03-07/6090778.html, accessed on 26 October 2021).

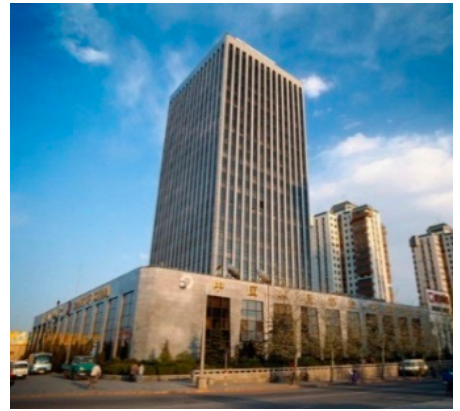

(a)

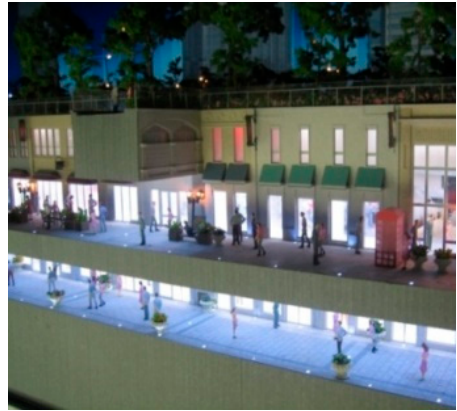

(b)

Figure 6. Cont. 


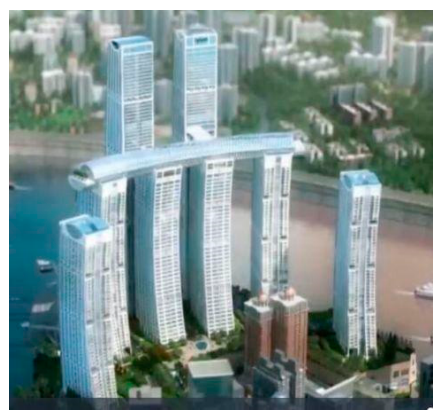

(c)

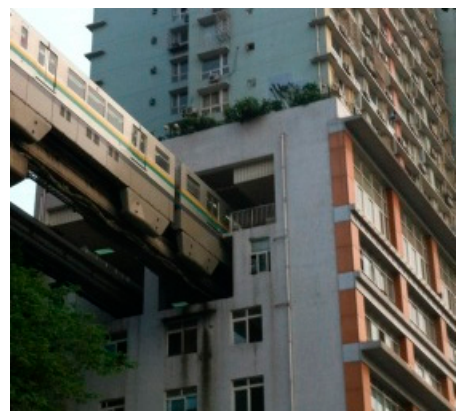

(d)

Figure 6. Spatial forms of buildings in urban areas: regular building (a,b); irregular building (c,d).

A realty registration incorporates the following information: (1) the physical conditions of the construction, such as the land location, boundaries, four neighbours, acreage, unique identification number, structure of existing construction, number of floors, area, intended use, etc., and (2) registration and rights information, such as the owner, use type, area of interest, transaction date, rights duration, business licenses, etc.

\subsection{Farmland, Forest Land, and Grassland}

According to the Chinese status of land use classification, "farmland" refers to land on which crops are planted in rural areas. According to the Forest Law of China, "forest land" means land that is covered by wildwood, secondary forests or artificial forests, including commercial forests, economic forests, protected forests, firewood forests, etc. "Grassland" refers to lands that are mainly covered by herbaceous plants, including both natural grassland and artificial grassland. The range of property rights for farmland, forest land and grassland does not include other types of properties, e.g., water areas, buildings, etc. A full consideration of the spatial locations of property units should be included during registration.

Figure 7 shows a current certificate of forest rights in China. Spatial information regarding the boundaries, four neighbours, or acreage is not provided in pictorial form. Furthermore, the spatial forms of farmland, forest land and grassland are complex in reality. Traditional 2D parcel maps cannot thoroughly illustrate this property, because most forest land and grass land exists on a 2.5D Earth surface. Therefore, current certificates of forest rights cannot represent forests and woodlands, and detailed information regarding forests and woodlands cannot be obtained based on these certificates.

Farmland and grassland can be regarded as "open type" properties, while the property units of forest lands should be regarded as "semi-delimited type" properties because their spatial forms can be separated into parts above and below the ground (Figure 8). Tree trunks and rhizome lies aboveground and underground, respectively (with certain heights or depths of the tree cylinder). This restricted spatial region may intersect with other property units, such as water and mines. Thus, the latter region should be regarded as adjoining, sharing common boundary surfaces with other property units.

The registration contents of this natural resource object include the rank information of the land in addition to the common physical information and rights information. The calculation methods of the area are different among flat ground, sloped ground and terrace fields. If the spatial form of sloped land is a continuous curved surface, then the property unit can be approximated by several adjacent flats, and the final acreage can be expressed by the sum of the area of every projective plane. If the form is a terrace field, the final acreage can be expressed by the sum of the acreage of all the projective polygons. 


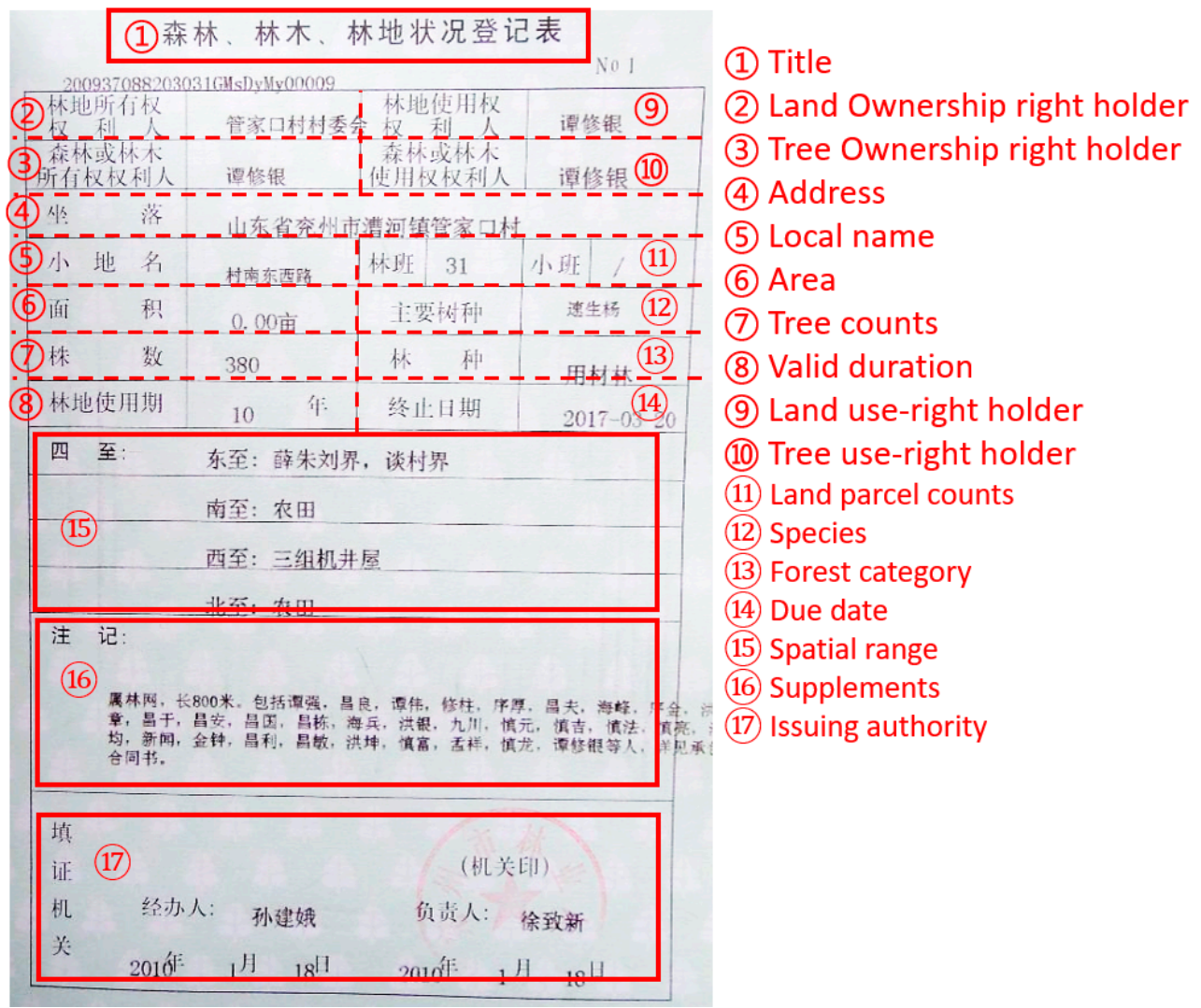

Figure 7. Certificate of forest rights from the People's Republic of China (source: https:/ / pic17.9977 88.com/_pic_search/00/03/14/20/3142062b.jpg, accessed on 26 October 2021).

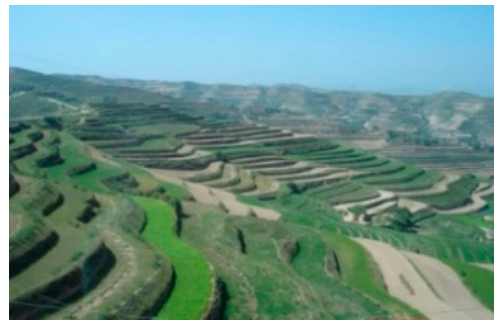

(a)

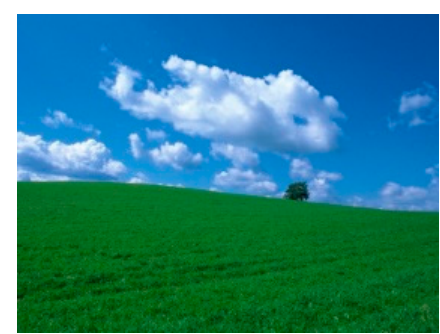

(b)

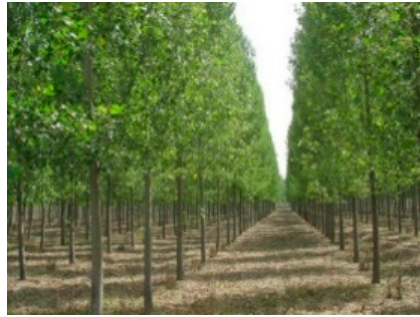

(c)

Figure 8. Spatial forms of property units. (a) farmland; (b) grassland; (c) forests.

\subsection{Construction Land}

According to the LALPRC, "construction land" means land on which construction projects and structures are built, including residential land in urban and rural areas, public facilities, and land for mining, industry, and transportation.

Figure 9 shows a registration chart for construction land. However, this registration simply demonstrates the construction land in a 2D model; details of spatial entities and components of the construction that are underground are not included in the current registration. 


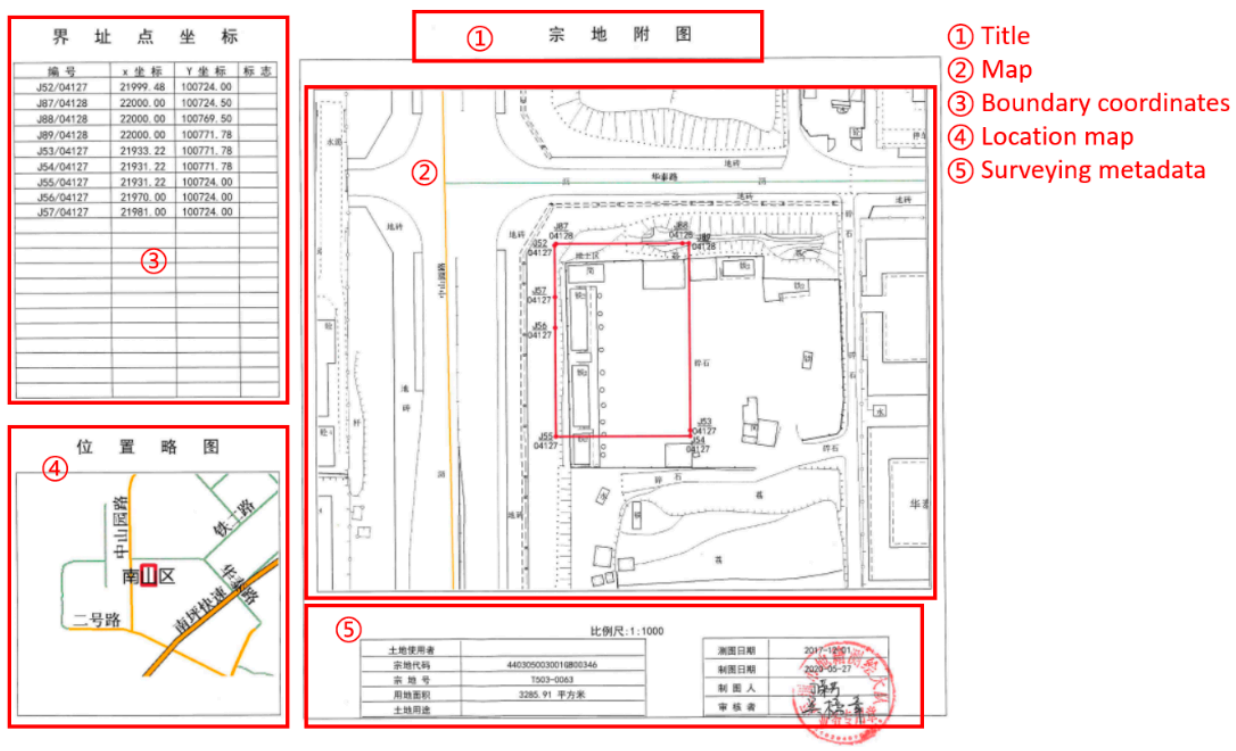

Figure 9. Parcel map of construction land (source: https: / /td.szggzy.com/tiaim/web/landDetail? $\mathrm{id}=20200912181648914840102076418611 \&$ code $=0015 \&$ goodId $=20200912181648908466638201444667$, accessed on 26 October 2021).

Examples of construction land are demonstrated in Figure 10. Construction land for specific usages, for instance, land for mining, industry and residential land in urban areas, also lie aboveground and underground. The spatial forms of aboveground areas are typically irregular. However, these property units can be considered "open type" properties. These realty registrations should incorporate physical conditions and rights information. The basic unit of mining areas should be defined by its longitude and latitude according to the Rules for the Implementation of the Mineral Resources Law of the People's Republic of China. The spatial forms of underground regions can be irregular in 3D space. Therefore, these forms can be considered "fully delimited type" properties because the ownership of the property is uniform (distinctions between exploration rights and mining rights should be considered). If the underground regions of a mining area intersect with other property units, such as buildings or ponds, then these sections of the property unit should be regarded as adjoining, sharing common boundary surfaces.

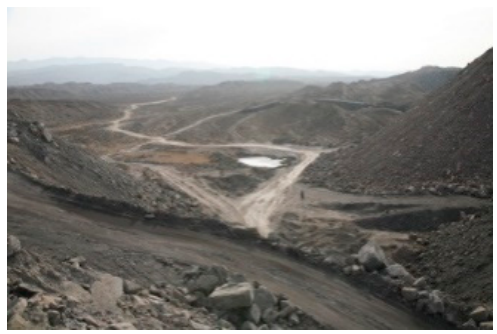

(a)

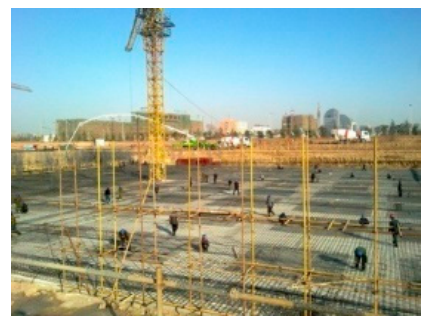

(b)

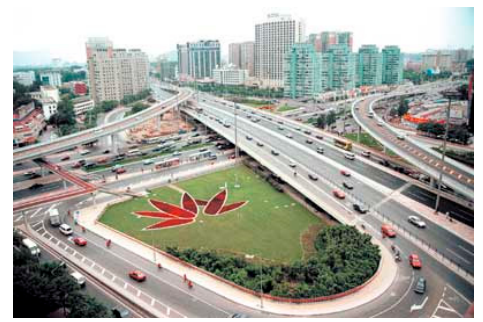

(c)

Figure 10. Spatial forms of construction land: (a) mining area; (b) building area; (c) construction land.

\subsection{Homestead Land}

Homestead land is collectively owned land that is occupied and utilized as residential land by peasant households or individuals in rural areas. Three main types of homesteads exist: (1) land on which houses have been built (Figure 11b), (2) land with roofless buildings that cannot provide living functions (Figure 11a), and (3) land that is intended for houses. 


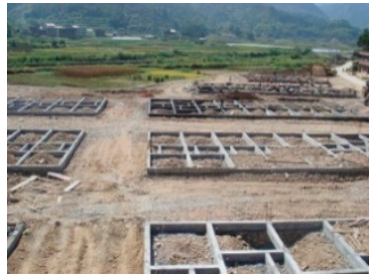

(a)

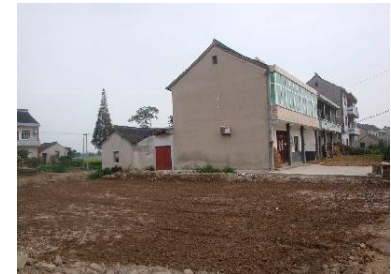

(b)

Figure 11. Spatial forms of homesteads: (a) homesteads without buildings; (b) homesteads with buildings.

A registration chart for a homestead is shown in Figure 12. The registration form and contents are consistent with the registration chart of construction land. Furthermore, the spatial forms of realistic homesteads are very complicated. Therefore, this demonstration includes only the area of the homestead and a profile of the building; the details of spatial entities and underground components are not included in current registrations, and detailed spatial information for the homestead cannot be obtained based on these figures in contemporary registrations.

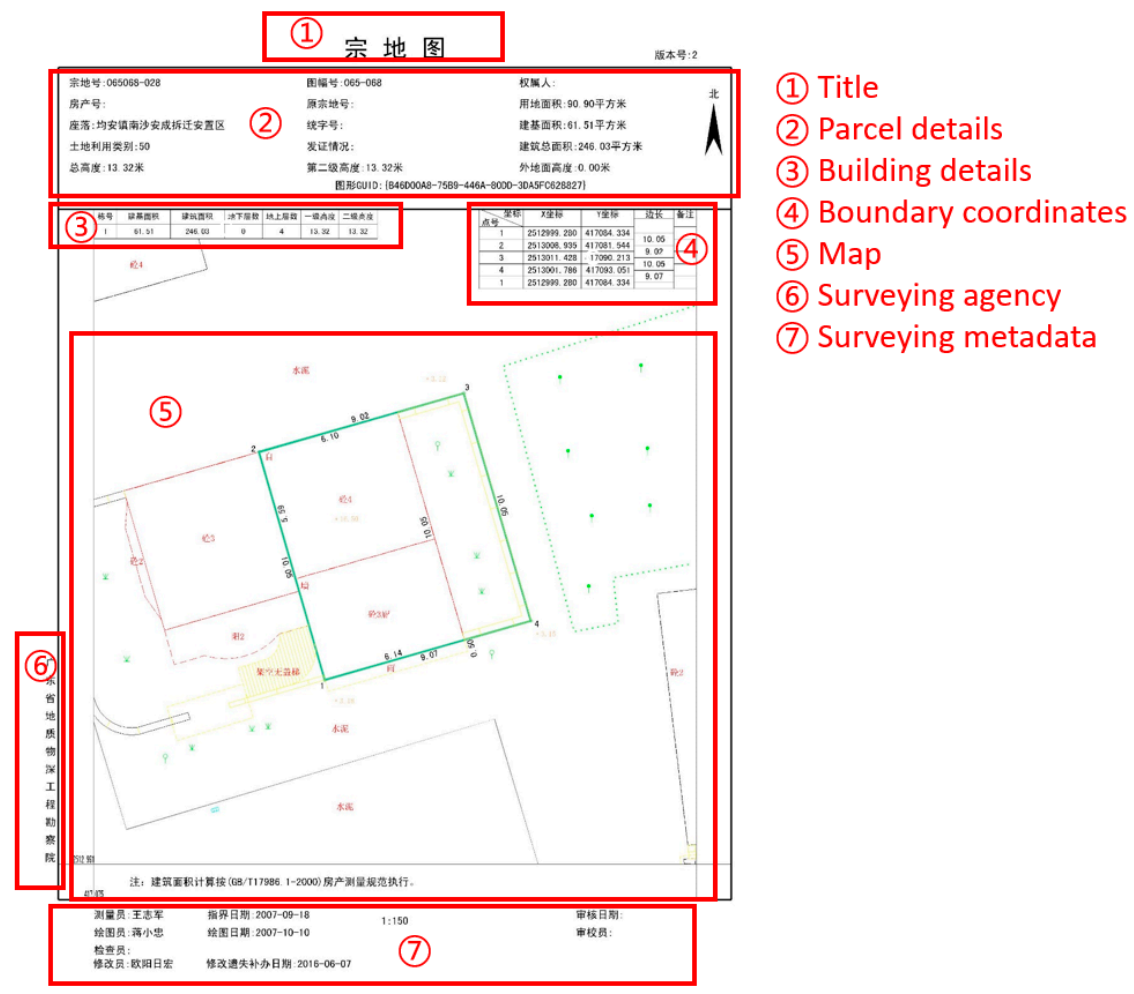

Figure 12. Parcel map of homestead land (source: http:/ / www.shunde.gov.cn/data/2016/09/23/1 474603486.jpg, accessed on 26 October 2021).

Homesteads should be regarded as "open type" properties represented by a 2D horizontal projective plane owned by a certain party. The land ownership and housing ownership of homesteads should be registered independently, and the contents of the registration should include the physical conditions and rights information (the specific contents of the registration should obey the Local Measures for the Management of Rural Homesteads).

\subsection{Water Areas}

A water area is a specific region that includes the scope and control limits of rivers, lakes, canals, channels, reservoirs, ponds, and related construction. 
Table 2 shows the registration table for a water area. However, the spatial forms of water areas are complicated in reality, and detailed and visualization information for water areas cannot be obtained from current registration tables.

Table 2. Registration table of a water area (source: http:/ /www.wl.gov.cn/art/2018/10/19/art_1402221_22027457.html, accessed on 26 October 2021).

\begin{tabular}{|c|c|c|c|c|c|}
\hline Applicant & Location & Geographical Coordinates (CSCS2000) & $\begin{array}{l}\text { Acreage } \\
\text { (Hectare) }\end{array}$ & $\begin{array}{l}\text { Breeding } \\
\text { Methods }\end{array}$ & $\begin{array}{l}\text { Deadline of the } \\
\text { Breeding Rights }\end{array}$ \\
\hline Chen Wengfu & $\begin{array}{c}\text { Dongqiaotou, Ruohen } \\
\text { Xilou } \\
\text { Jielongtou } \\
\text { Xinji }\end{array}$ & $\begin{array}{l}\text { N28 } 28^{\circ} 04.397^{\prime \prime} \mathrm{E} 121^{\circ} 30^{\prime} 02.064^{\prime \prime} \\
\text { N28 } 20^{\prime} 03.080^{\prime \prime} \text { E121 } 29^{\prime} 37.821^{\prime \prime} \\
\text { N28 } 19^{\prime} 58.749^{\prime \prime} \mathrm{E} 121^{\circ} 30^{\prime} 01.313^{\prime \prime} \\
\text { N28 } 28^{\circ} 05.604^{\prime \prime} \mathrm{E} 121^{\circ} 29^{\prime} 38.197^{\prime \prime}\end{array}$ & 9.292 & pond & $\begin{array}{l}29 \text { October } 2018 \text { to } \\
28 \text { October } 2019\end{array}$ \\
\hline
\end{tabular}

Examples of water areas are illustrated in Figure 13. Water areas can be considered as "open type" properties if their ownership is uniform; they can also be regarded as "semidelimited type" properties when the ownership of resources under the water's surface is considered. Generally, the range of the property can be defined by the scope of the water area's surface, and the 3D entity can be represented by a 2D horizontal projective plane. In this case, the realty registration should include the common information for natural resources registration. The contents of the registration should include the physical conditions and rights information. If the components of the property unit under the water's surface intersect other property units, then these areas of the property units should be regarded as adjoining, sharing common boundary surfaces.

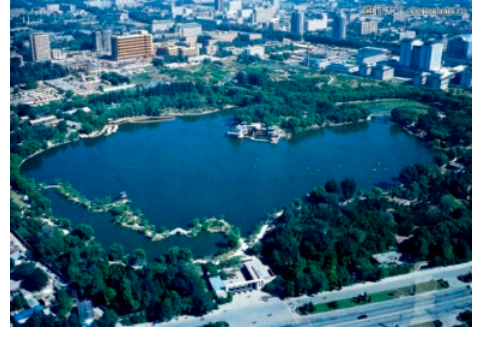

(a)

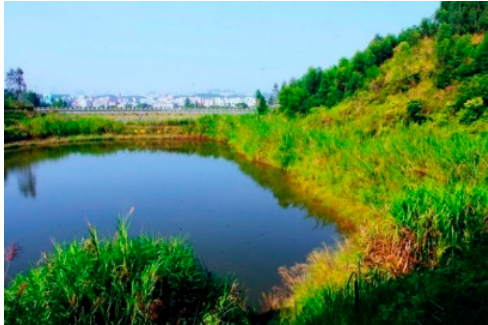

(b)

Figure 13. Spatial forms of water areas: (a) water area in a city; (b) water area in the countryside.

\subsection{Sea Areas}

"Sea areas" refer to specific ocean areas, including both above-water and underwater areas. According to the Law of the People's Republic of China on the Administration of the Usage of Sea Areas (LPRCAUSA), sea areas in China include interior waters, the surfaces of territorial waters, water bodies, sea areas, and subsoil. Interior waters lie between the extent of territorial waters and the coastline.

Figure 14 shows a registration table for a sea area. However, the spatial forms of sea areas are complicated in reality; thus, a traditional 2D parcel map cannot fully illustrate the natural resource, and detailed visualized information for the sea area cannot be obtained based on current registration tables.

According to the LPRCAUSA, the registration (right of use) materials of specific realty, such as sea areas, should incorporate the intended use, coordinate graphs, functional zoning, boundaries, acreage, space, location, and other sea area properties.

Starting on 1 March 2015, the natural resources (sea) registration certificate (as shown in Figure 15) issued by the Ministry of Land and Resources of the People's Republic of China have been formally applied, and the various types of natural resource registration books used before ceased being issued. However, the existing objects of real estate registration are complicated, as shown in Table 3. Property rights are no longer restricted to 2D space but are increasingly becoming associated with 3D space. Therefore, the NRUM model in this paper must comprehensively describe property units in $2 \mathrm{D}, 3 \mathrm{D}$, and hybrid spaces. 


\section{(1) 公告}

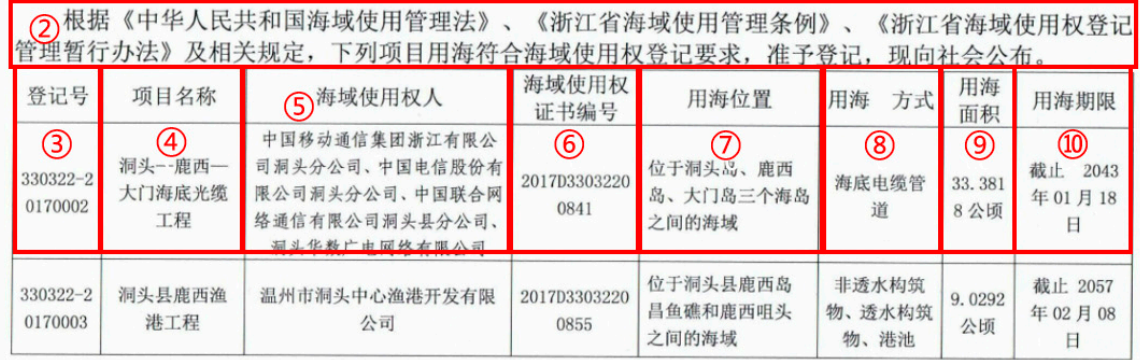

公民、法人或者其他组织认为海域使用权登记侵犯其合法权益的，可以根据《行政复议法》《行政近 讼法》有关规定,提出行政复议申请或者向人民法院提起行政诉讼。

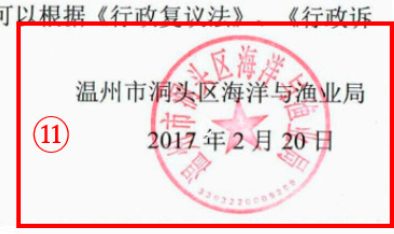

(1) Title

(2) Legal basis

(3) Registration No.

(4) Project name

(5) Use-right holder

(6) Certificate code

(7) Address

(8) Usage

(9) Area

(10) Life span

(11) Issuing authority

Figure 14. Registration table of a sea area (source: http: / zjjcmspublic.oss-cn-hangzhou-zwynet-d01-a.internet.cloud.zj. gov.cn/jcms_files/jcms1/web1832/site/picture/0/1702201120428293339.jpg, accessed on 26 October 2021).

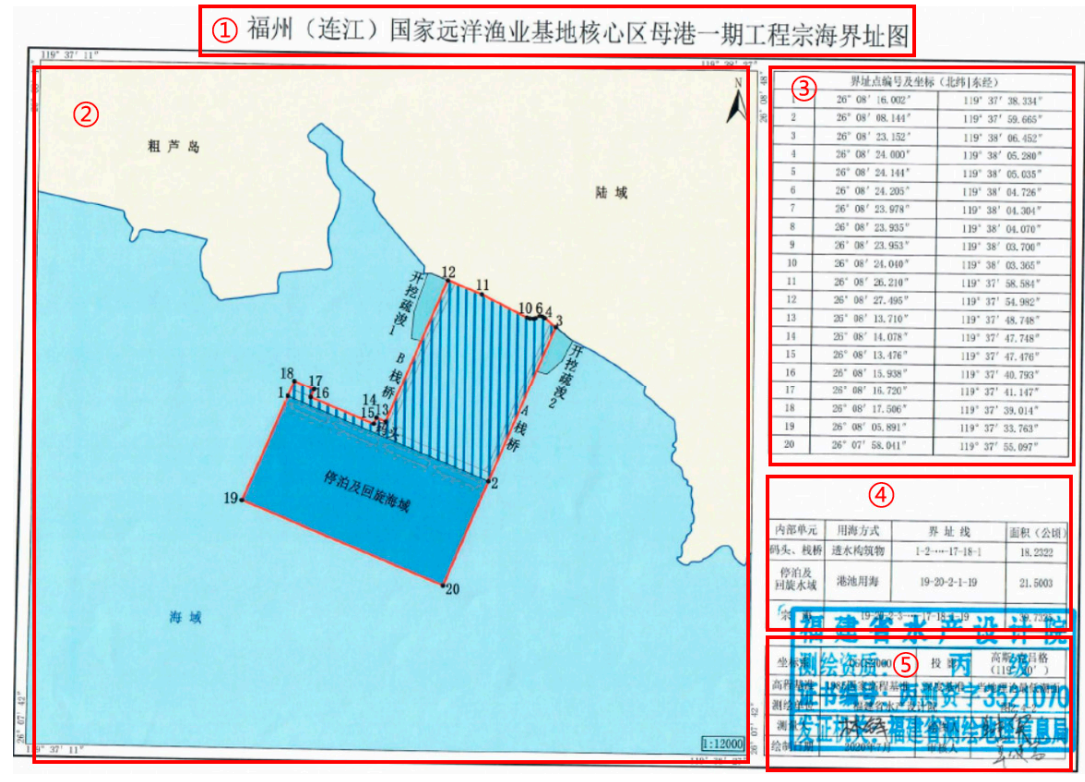

(1) Title

(2) Map

(3) Boundary coordinates

(4) Parcel description

(5) Surveying metadata

Figure 15. Natural resource registration (sea) certificate (source: http://www.fzlj.gov.cn/xjwz/zwgk/zfxxgkzl/ xrmzfgzbm_11124/ljxgtzyj/gkml/202010/P020201027539307826081.pdf, accessed on 26 October 2021).

Table 3. Objects in the NRUM.

\begin{tabular}{|c|c|c|c|c|}
\hline & & Spatial Forms & Contents of Registration & $\begin{array}{l}\text { Spatial Relationship } \\
\text { with Others }\end{array}$ \\
\hline \multicolumn{2}{|c|}{ Collective land } & Open type & $\begin{array}{l}\text { Holder of the realty (collective), type of the natural resource, contents of the } \\
\text { rights, source of the rights, code, location, boundaries, spatial boundaries, } \\
\text { acreage, usage, life span, change of the rights, etc. }\end{array}$ & Adjoin, include \\
\hline \multirow{2}{*}{ Construction } & Regular & \multirow{2}{*}{ Fully delimited type } & \multirow{2}{*}{$\begin{array}{l}\text { (1) Physical conditions, location, boundaries, acreage, code, usage, etc.; } \\
\text { (2) situation of the rights, holder of the realty, type of the rights, contents of } \\
\text { the rights, source of the rights, change of the rights, record date, term, etc. }\end{array}$} & \multirow{2}{*}{ Adjoin } \\
\hline & Irregular & & & \\
\hline
\end{tabular}


Table 3. Cont.

\begin{tabular}{|c|c|c|c|c|}
\hline \multicolumn{2}{|c|}{ Name } & Spatial Forms & Contents of Registration & $\begin{array}{l}\text { Spatial Relationship } \\
\text { with Others }\end{array}$ \\
\hline \multicolumn{2}{|c|}{ Structures } & Open type & $\begin{array}{l}\text { Holder of the realty, type of the natural resource, contents of the rights, } \\
\text { source of the rights, code, location, boundaries, spatial boundaries, acreage, } \\
\text { usage, life span, change of the rights, etc. }\end{array}$ & Adjoin \\
\hline \multicolumn{2}{|c|}{ Farmland, grassland } & Open type & $\begin{array}{l}\text { Holder of the realty, type of the natural resource, contents of the rights, } \\
\text { source of the rights, code, location, boundaries, spatial boundaries, acreage, } \\
\text { usage, level, life span, change of the rights, etc. }\end{array}$ & Adjoin, include \\
\hline \multicolumn{2}{|c|}{ Forest land } & Semi-delimited type & $\begin{array}{l}\text { Holder of the realty, type of the natural resource, contents of the rights, } \\
\text { source of the rights, code, location, boundaries, spatial boundaries, acreage, } \\
\text { usage, level, life span, change of the rights, etc. }\end{array}$ & Adjoin, include \\
\hline \multirow{2}{*}{$\begin{array}{l}\text { Construction } \\
\text { land }\end{array}$} & $\begin{array}{l}\text { For mining and } \\
\quad \text { residence }\end{array}$ & $\begin{array}{l}\text { Over ground, open } \\
\text { type; underground, } \\
\text { fully delimited type }\end{array}$ & $\begin{array}{l}\text { (1) Physical conditions, location (longitude and latitude), boundaries, code, } \\
\text { acreage, usage, etc.; (2) situation of the rights, code of the rights, obligee, } \\
\text { legal nature, life span, type of the rights, contents of the rights, source of the } \\
\text { rights, change of the rights, etc. }\end{array}$ & Adjoin \\
\hline & Others & Open type & $\begin{array}{l}\text { Holder of the realty, code, type of the natural resource, contents of the rights, } \\
\text { source of the rights, name of the owner, location, boundaries, spatial } \\
\text { boundaries, acreage, life span, usage, legal nature, change of the rights, etc. }\end{array}$ & Adjoin \\
\hline \multicolumn{2}{|c|}{ Homestead } & Open type & $\begin{array}{l}\text { (1) Physical conditions, parcel code, figure code, acreage of the parcel, } \\
\text { location, Fhouse code, structure, usage, etc.; (2) situation of the rights, legal } \\
\text { nature of the land, life span, obligee, source of the rights, name of the owner, } \\
\text { type of the rights, contents of the rights, source of the rights, change of the } \\
\text { rights, etc. }\end{array}$ & Adjoin \\
\hline \multicolumn{2}{|c|}{ Water area } & Open type & $\begin{array}{l}\text { Holder of the realty, code, type of the natural resource, location, boundaries, } \\
\text { spatial boundaries, acreage, usage, life span, change of the rights, etc. }\end{array}$ & Adjoin \\
\hline \multicolumn{2}{|c|}{ Sea area } & Open type & $\begin{array}{l}\text { Application of sea-area use, coordinate graphs of the sea area, functional } \\
\text { zoning of the sea area, boundaries of the sea area, acreage, owner, term, } \\
\text { change of the rights, etc. }\end{array}$ & Adjoin \\
\hline
\end{tabular}

\section{Construction of an NRUM Model}

The LADM focuses on the areas of land administration that are mainly connected to real properties, land ownership and the geometrical (spatial) components of natural resources [31]. This model provides a framework to extend property models to fit different administrative systems. In this case, a suitable NRUM model for the national conditions in China can be established based on land usage and political party by extending the existing LADM framework. According to the requirements of natural resources unification (described in Section 3) and the analysis of the spatial forms of natural resources in China (described in Section 4), the uniform natural resources model that is explained in this section can be separated into four basic categories referenced from LADM to achieve the goal of unification: the unification of land space, the unification of natural resources, the unification of geometry representation, and the unification of party and RRRs.

The basic classes of the uniform natural resource model and the relationships between them are demonstrated in Figure 16. The geospace class as the core class of the NRUM represents the unified and non-overlapped space that holds full natural resources and their relevant activities. The natural resource (NR) class describes objects' ontological attributes and the constitutional system (natural ontology in other words). To depict the shape structure and the quantifiable geometry relationship of geospace and NRs, the geometry representation class undertakes the task. Meanwhile, when people or organizations interact with the natural resources, this interaction declares the characters of property and the party, and the RRR class is established to address this issue. According to the four basic categories, the NRUM utilizes the existing structure of the LADM. 


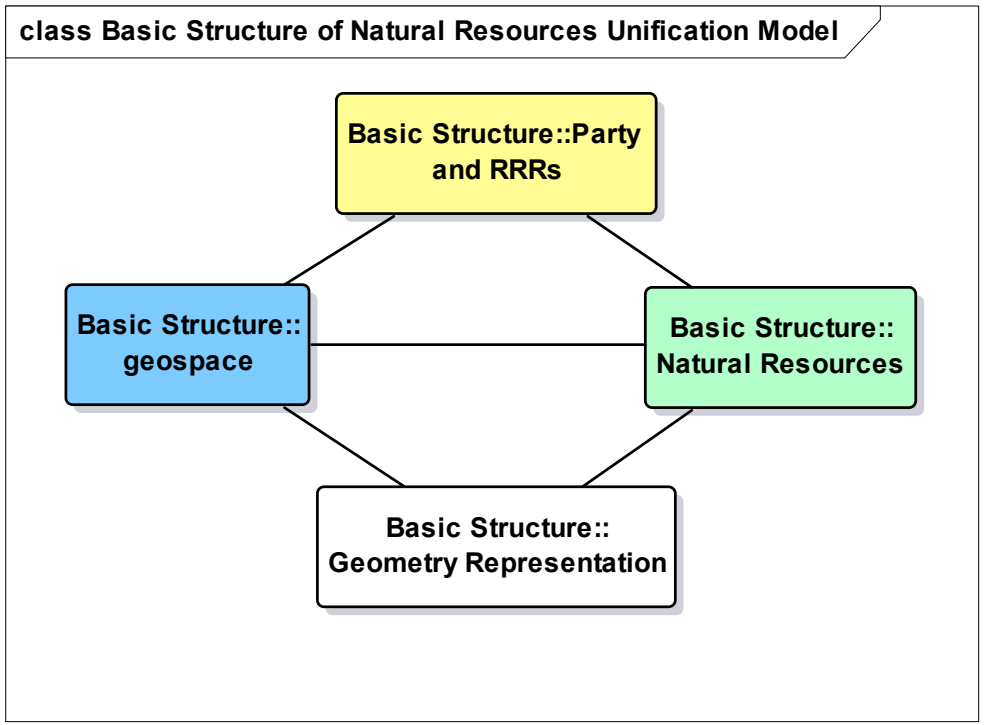

Figure 16. Relationships between the four basic classes of uniform natural resource model.

\subsection{Geospace}

Unified geospace modelling is based on the absoluteness of the geographic space; thus, the 3D representation of the geospace is necessary. Nonetheless, in China, the twodimensional representation cannot be abandoned completely, because a large number of existing systems are still based on the 2D form, and a viable approach is to develop a 3D management system compatible with a 2D representation. In the model, our geographic space is divided into subspace units that are often determined according to specific needs. However, in a unified space, all subspace units are non-overlapping and can fully fill the space (Figure 17). At the same time, each subspace unit can be further divided into more detailed child spatial units until the most detailed granularity is satisfied. This granularity of detail usually depends on parties, organizations, and countries in the management and utilization of natural resources. If one subspace unit is with multiple cardinality with multiple natural resource units, it indicates that multiple natural resources coexist in the space.

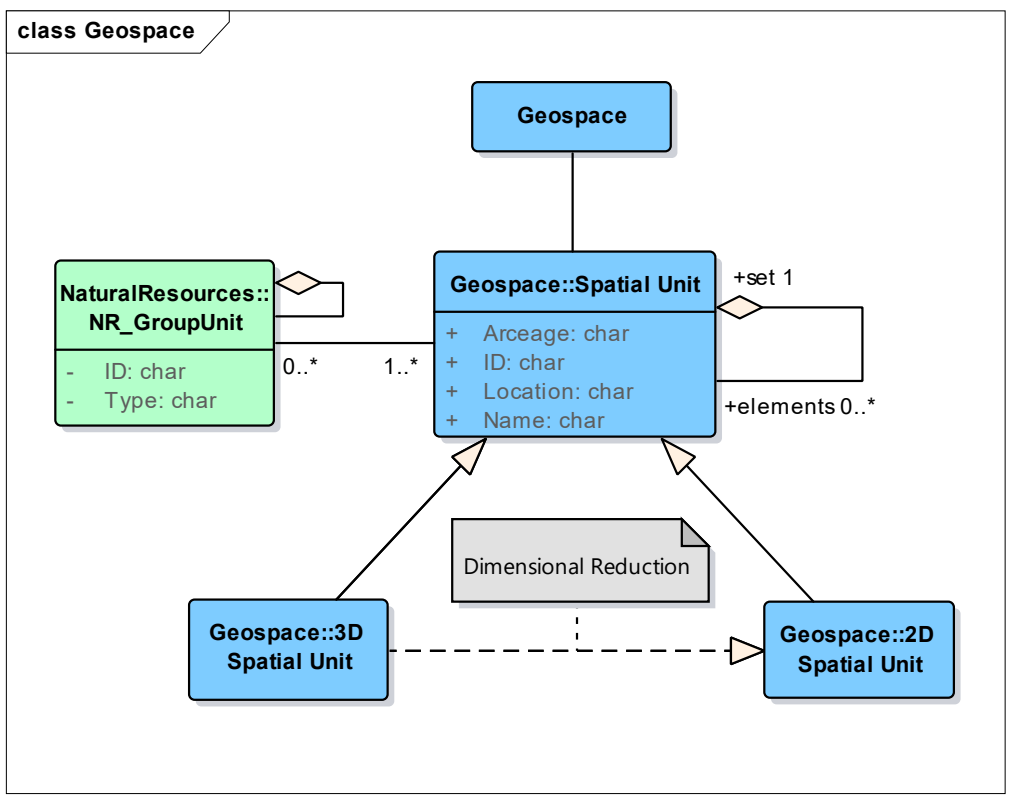

Figure 17. Geospace class. 


\subsection{Natural Resources}

Natural resources are abstract concepts that are more complex that land resources and include land, infrastructure that is located on the land, living environments, and other areas, such as water, forests, and so on [27,32]. Natural resource objects involve geographic areas both above and below the ground, e.g., the right to use forests and land covered by these forests may not be owned by the same party. In this case, the natural resource objects must be considered as $3 \mathrm{D}$ elements, because they exhibit both depth and area. The 271th article of the Chinese Civil Code states that the owner of apartments or commercial buildings is entitled to the ownership over exclusive sections of the building but common ownership and management rights over the communal areas of the building. The detail explanation of 5th article of the IRRER states that land without houses should be registered as a parcel and recorded in the land portion of the registration book. It can be seen that natural resources and geographic space were used as an integration in the past. From the aspect of object management, each type of natural resource has become an isolated individual, which cannot fully describe the integrity and systematic character of natural resources in a space. Therefore, in the NRUM, natural resources are described as an independent individual.

According to Section 3.2, and considering the original independent characteristics of each type of natural resource, full natural resources must be able to independently describe the unified geographic space, and the relationship between natural resources also needs to be considered. In the model, the independent system of natural resources is described by natural resource units and basic units, and the relationships between different natural resources are described by different types of resources aggregated into a group unit (Figure 18). For example, a forest park unit can be composed of several different types of forest units and constructions.

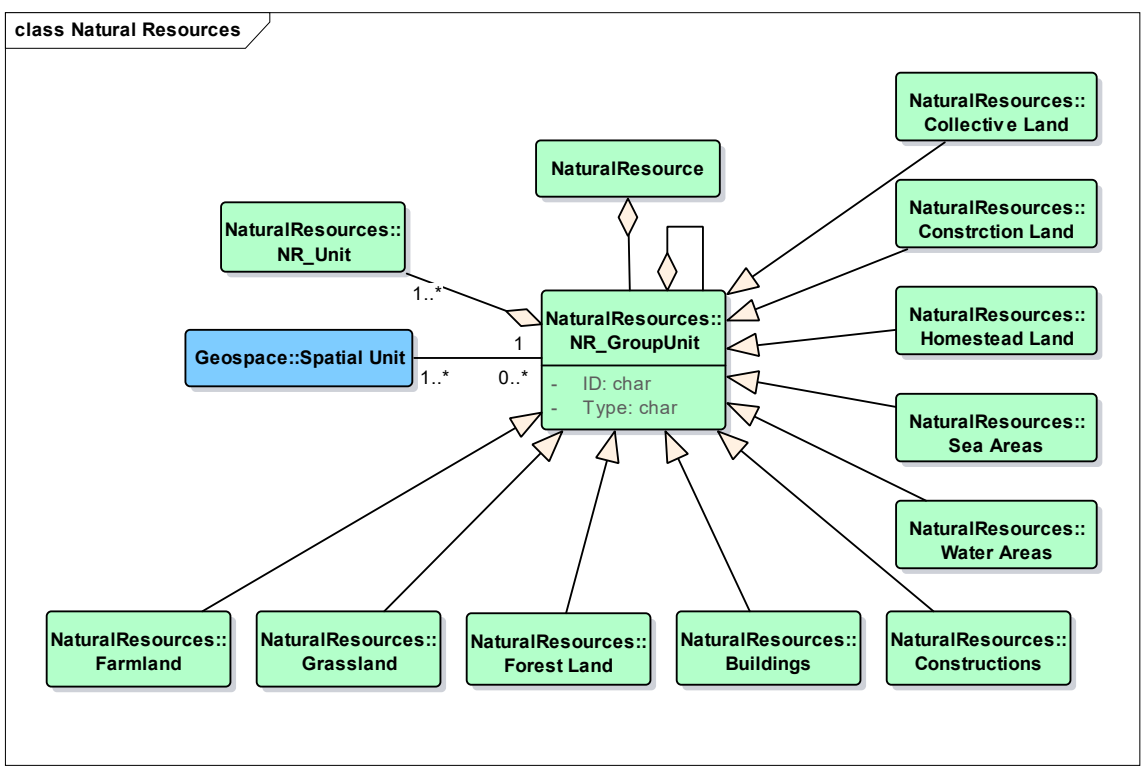

Figure 18. Natural resource class.

\subsection{Geometry}

A uniform geometric representation of natural resources is very important. A natural resource class includes three layers: an object layer, a topological layer, and a geometrical layer. The three-tier structure represents a realistic description from basic geometric units to natural resources, and a description of geometry and topology between natural resources or $3 \mathrm{D}$ objects can be found in $[23,28,33,34]$.

Natural resource objects can be separated into three geometric types; these types can be characterized by 2D, 2.5D, and 3D spatial forms. Regardless of the spatial form, we can generalize the objects according to geometric points, arcs, planes, and bodies. 
The representation of 3D features is diminished in a 2D form; thus, a uniform geometric representation should adopt a 3D representation.

In the NRUM, the geometric representation can be divided into object vectors and voxels, as in Figure 19. In the vector representation, the basic measurement unit of the LADM's surveying and representation package is used as the basis. Specific topological relationships are required to precisely describe complicated 3D objects and are helpful for deep data mining, such as spatial analysis and calculation [27]. Thus, the topological geometry described in $[23,28,33,34]$ can support the essential requirements as well as the target point, arc, surface, or body. For the voxel representation, natural resources are directly represented by basic volumetric primitives that are regular primitives, voxel and irregular primitives, and constructive solid geometry. The voxel representation takes regular tetrahedron, hexahedron, octahedron, dodecahedron, and icosahedron shapes as primitives, and constructive solid geometry is used by user-defined primitives.

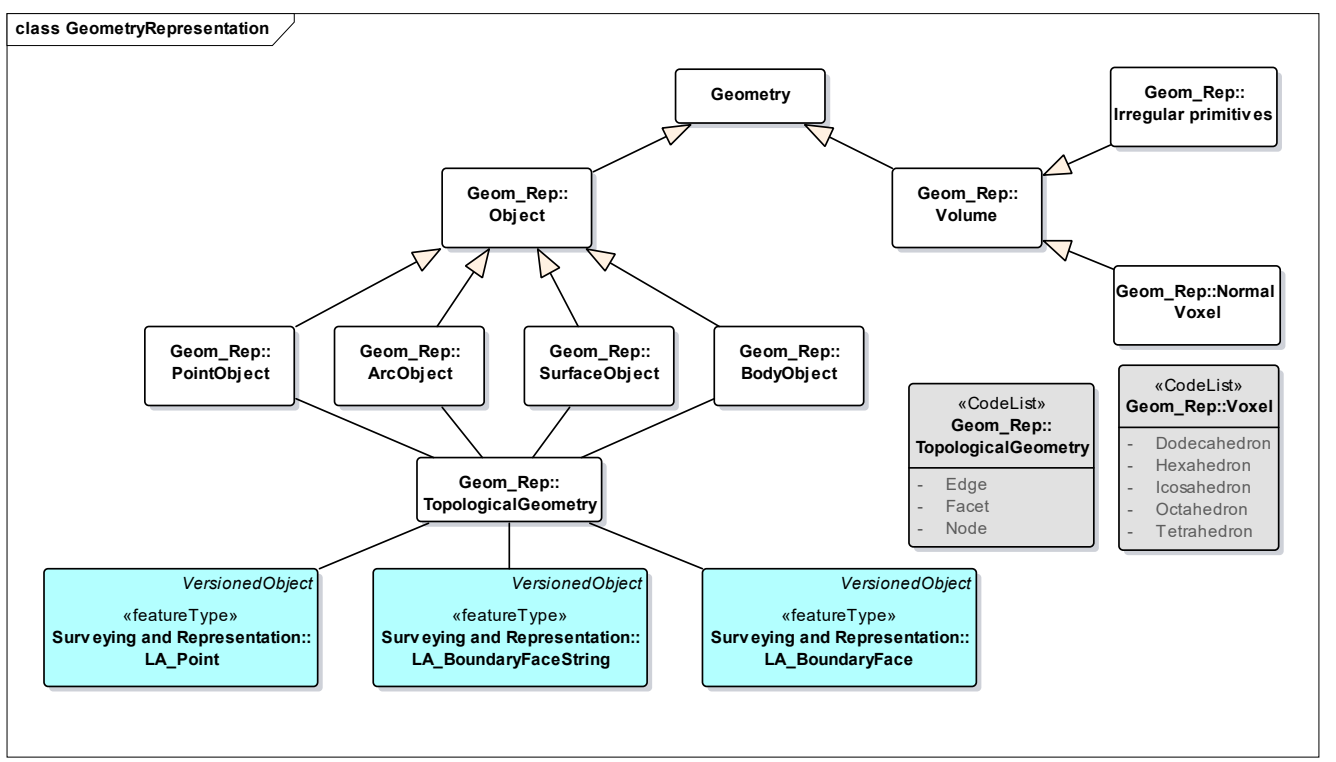

Figure 19. Physical layer of the natural resource class.

\subsection{Party and RRR}

\subsubsection{Party}

Ownership of land in China is limited to the state and collectives by constitutional law. According to the 324th article of the Chinese Civil Code, an individual or organization can possess and use natural resources as well as benefit from them. At the same time, the 247th article states that mineral deposits and water and sea areas shall be owned by the state, and the 329rd article states that mineral-prospecting rights, mining rights, water-intake rights, and the right to use water areas or tidal flats for breeding or fisheries shall be under the protection of the law. Moreover, the 331th article states that the holder of the contracted management right of the land shall enjoy the right to possess, use the farmland, woodland, grassland, and water and benefit from them by engaging in planting, forestry, stockbreeding, or other agricultural production activities.

Above all, the parties in the NRUM model include natural and non-natural people. Non-natural people include the state, collectives, and other organizations in China. The natural resource rights holder has different characteristics based on the rights that they own. For example, a rights holder who possesses ownership of a house may simultaneously be the holder of the right to use the land on which the house is located. A group party must contain two or more members. The aggregate association between a group party and party can be further categorized into an association of class "members", in which certain characteristics of each member are maintained. 


\subsubsection{RRR}

According to the Chinese Civil Code and the IRRER, property rights can be summarized as ownership, real rights for the usufruct, and real rights for security.

\section{Ownership}

Ownership in China mainly includes state ownership, collective ownership, and private ownership. According to the relevant laws in China, all mineral resources, waters, forests, mountains, grassland, un-reclaimed land, beaches, and other natural resources are owned by the state or owned by the entire population, with the exception of forests, mountains, grasslands, and un-reclaimed land and beaches, which are owned by collectives in accordance with the law. Land in cities is owned by the state, and land in rural and suburban areas is owned by collectives. The only exceptions are those portions that belong to the state in accordance with the law. Housing sites, privately farmed plots of cropland, and hilly land are also owned by collectives.

\section{Usufruct Right}

According to the 323th article of the Chinese Civil Code, a usufruct rights holder shall have the right to possess, use and seek proceeds from real property or movable property that is owned by himself according to legal provisions. Usufruct rights include rural contracted management rights of land as well as use rights of construction land and easements. The 329rd article states that mineral-prospecting rights, mining rights, water-intake rights, and the right to use water areas or tidal flats for breeding or fishery shall be under the protection of the law. The 330th and 331th articles of the Chinese Civil Code state that the system of land-contract management shall be adopted for farmland, woodland, grassland, and other land for agricultural uses that are owned by farmers collectives and land that is owned by the state but used by farmers' collectives. The holder of the contracted management right of land is entitled to use and benefit from farmland, woodland, grassland, etc. The 362nd article of the Chinese Civil Code states that the holder of the homestead site use right shall be entitled to possess and use land that is owned by a collective and make use of that land to construct residential houses and their affiliated facilities.

\section{Security Rights}

Real rights for security stand in contrast to the usufruct rights. These rights exist to ensure the realization of creditor rights, whose contents are directly obtained from or dominate the exchange value of the property. Security rights can be seen as a type of restriction; at present, only mortgages belong to real rights for security (Figure 20). The 395th article of the Chinese Civil Code states that the following properties about natural resources that the obligor or third party has the right to dispose could be used for mortgage: (1) buildings and other fixed constructions on the ground; (2) use rights of construction land; and (3) the contracted management rights of land obtained by bid invitation, auction, public consultation, etc.

Moreover, the 399th article of the Chinese Civil Code states that the following properties about natural resources is not allowed to be mortgaged: (1) land ownership and (2) the use rights of collective land, farmland, homestead land, and land that is set aside for farmers to cultivate for their private use, unless otherwise stipulated by law. 


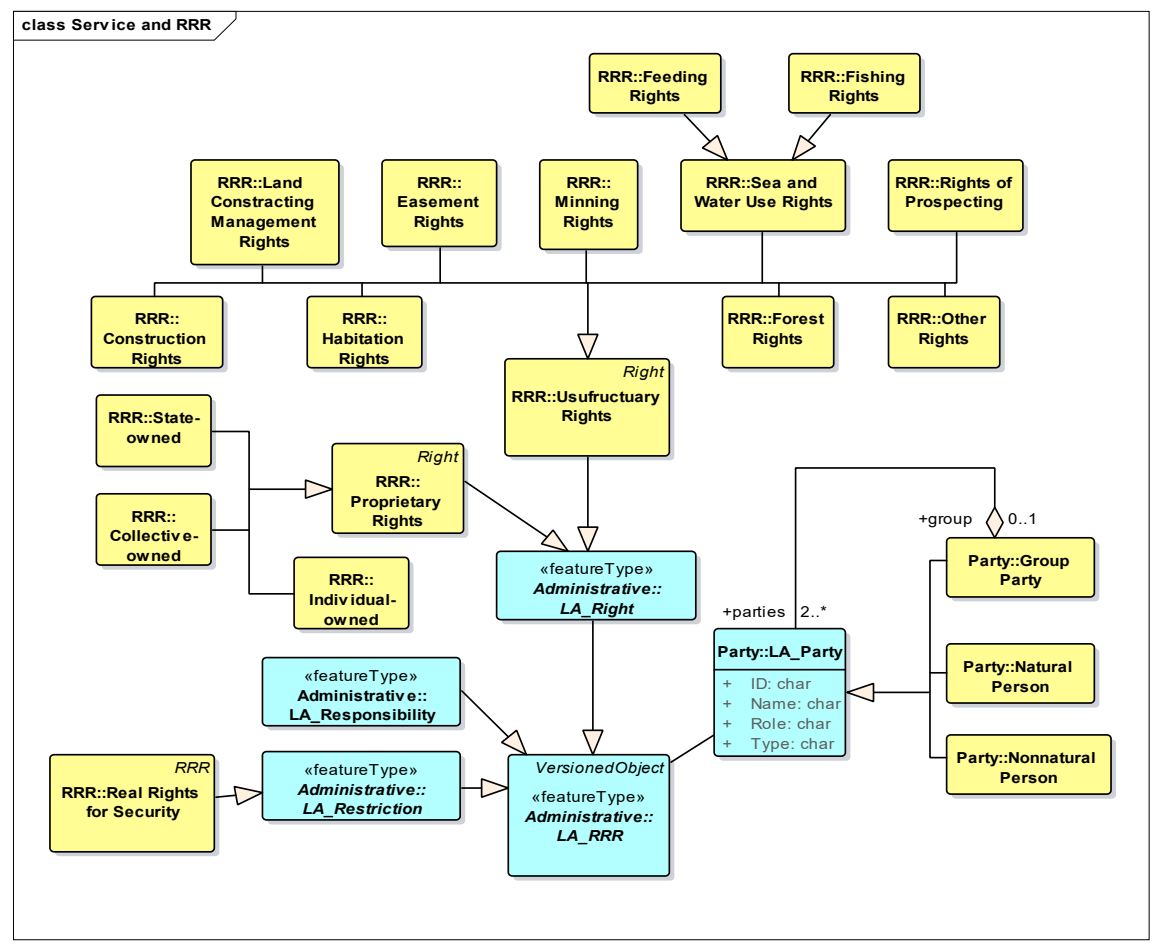

Figure 20. Party and RRR class.

\section{Conclusions}

New requirements from the new MNRPRC and IRRER have promoted the uniform registration and management of full natural resources in 3D geographic space. This paper proposes a uniform natural resources registration model that is suitable for China based on the requirements of uniform natural resource registration and an analysis of the spatial form of natural resources. Historical revolution of government indicates the idea of promotion and innovation, especially considering the management of geographic natural objects and real estates. China has explored a new vision about uniform registry about real estate/land space to fit Chinese road, and this has promote the revision of ISO 19,152 to adapt new trend. Combined with detailed descriptions and structures of the LADM, three basic packages, including natural resources, geometry, and party, and RRRs are extracted from the aforementioned relevant laws and regulations. More importantly, the proposed conceptual model has been used for the registration and management of parcels and buildings in Shenzhen, which has demonstrated that the framework of resource management and technical support are effective and feasible. For example, real 3D parcels of oversea bridge with multiple jurisdiction in the Shenzhen Bay Port that are regulated by Shenzhen government and by Hong Kong government [18]. A special Qianhai Zone in Shenzhen has been enforced to plan, construction and manage with full 3D framework in urban environment. With our promotion of 3D cadastral technique all over China, uniform modelling and registration of natural resources and real estate will tend to be more systematic and integrated to be mature supporting our national land uniform planning and management.

Author Contributions: S.Y., C.L., N.C. and Y.J. performed the analysis and drafted the manuscript. S.Y., R.G. and L.L. contributed to the conception of the study. All authors have read and agreed to the published version of the manuscript.

Funding: This research was funded by the National Natural Science Foundation of China (No. 42071366).

Institutional Review Board Statement: Not applicable.

Informed Consent Statement: Not applicable. 


\section{Data Availability Statement: Not applicable.}

Conflicts of Interest: The authors declare no conflict of interest.

\section{References}

1. Drobež, P.; Fras, M.K.; Ferlan, M.; Lisec, A. Transition from 2D to 3D real property cadastre: The case of the slovenian cadastre. Comput Environ. Comput. Environ. Urban Syst. 2017, 62, 125-135. [CrossRef]

2. International Organisation for Standardisation. ISO 19152:2012, Geographic Information-Land Administration Domain Model (LADM); ISO: Geneva, Switzerland, 2012. Available online: https:/ /www.iso.org/standard/51206.html (accessed on 12 February 2019).

3. Gao, S.P.; Shen, C. Several issues of natural resource mortgage registration: From the perspective of regulations of natural resource registration. J. Soc. Sci. 2014, 5, 93-100.

4. Guo, R.Z.; Ying, S.; Li, L. Automatic construction of 3D cadastral objects based on facet sets. Acta Geod. Sin. 2012, 41, 620-626.

5. Guo, R.Z.; Luo, F.; Zhao, Z.; He, B.; Li, L.; Luo, P.; Ying, S. The ap plications and practices of 3D cadastre in Shenzhen. In Proceedings of the 4th International Workshop on 3D Cadastres, Dubai, United Arab Emirates, 9-11 November 2014 ; pp. 299-312.

6. Guo, R.Z.; Ying, S. Three-dimension cadastre analysis and data delivery. China Land Sci. 2010, $24,45-51$.

7. He, H.L.; Jiang, D.; Zhang, P. Discussion on developing China's unified natural resource registration system: A transitional solution for the problems of divided registration system. China Land Sci. 2013, 24, 10-14.

8. Lemmen, C.; Van Oosterom, P.J.M.; Bennett, R. The land administration domain model. Land Use Policy 2015, 49, 535-545. [CrossRef]

9. Lin, H.G.; Guo, R.Z. Design of 3D cadastre conceptual model. Geomat. Inf. Sci. Wuhan Univ. 2006, 7, $643-645$.

10. Van Oosterom, P.J.M.; Lemmen, C.; Ingvarsson, T.; Van der Molen, P.; Ploeger, H.; Quak, W.; Stoter, J.; Zevenbergen, J. The core cadastral domain model. Comput. Environ. Urban Syst. 2006, 30, 627-660. [CrossRef]

11. Hanus, P.; Pęska-Siwik, A.; Benduch, P.; Szewczyk, R. Comprehensive Assessment of the Quality of Spatial Data in Records of Parcel Boundaries. Measurement 2020, 158, 107665. [CrossRef]

12. Pouliot, J.; Wang, C.; Hubert, F.; Ellul, C.; Rajabifard, A. 3D cadastre visualization: Recent progress and future directions. In Proceedings of the International FIG Workshop on 3D Cadastres, Athens, Greece, 18-20 October 2016; pp. 337-360.

13. Shi, J.N. Research on Unified Natural Resource Registration System of China. Ph.D. Thesis, Nanjing Agriculture University, Nanjing, China, 2009.

14. Stoter, J.E.; Ploeger, H.D. Property in 3D—registration of multiple use of space: Current practice in Holland and the need for a 3D cadastre. Comput. Environ. Urban Syst. 2003, 27, 553-570. [CrossRef]

15. Jeong, D.H.; Jang, B.B.; Lee, J.Y.; Hong, S.I.; Van Oosterom, P.J.M.; de Zeeuw, K.; Stoter, J.; Lemmen, C.; Zevenbergen, J.A. Initial design of an LADM-based 3D Cadastre-Case study from Korea. In Proceedings of the 3rd International FIG Workshop on 3D Cadastres: Developments and Practices, Shenzhen, China, 25-26 October 2012; pp. 159-184.

16. Kim, S.; Heo, J. Development of 3D underground cadastral data model in Korea: Based on land administration domain model. Land Use Policy 2017, 60, 123-138. [CrossRef]

17. Kim, S.; Heo, J. Registration of 3D underground parcel in Korean cadastral system. Cities 2019, 89, 105-119. [CrossRef]

18. Guo, R.Z.; Ying, S.; Li, L.; Luo, P.; Van Oosterom, P.J.M. A multi-jurisdiction case study of 3D cadastre in Shenzhen, China as experiment using the LADM. In Proceedings of the 2nd International Workshop on 3D Cadastres, Delft, The Netherlands, 16-18 November 2011; pp. 34-50.

19. Wang, C. 3D Visualization of Cadastre: Assessing the Suitability of Visual Variables and Enhancement Techniques in the 3D Model of Condominium Property Units. Ph.D. Thesis, Laval University, Québec, QC, Canada, 2015.

20. Wang, W.L. The Construction and System Implementation of Three-Dimensional Cadastral Data Model. Ph.D. Thesis, Zhejiang University, Hangzhou, China, 2012.

21. Van Oosterom, P. Research and development in 3D cadastres. Comput. Environ. Urban Syst. 2013, 40, 1-6. [CrossRef]

22. Li, L.; Wu, J.; Zhu, H.; Duan, X.; Luo, F. 3D modeling of the ownership structure of condominium units. Comput. Environ. Urban Syst. 2016, 59, 50-63. [CrossRef]

23. Yu, C.; Li, L.; He, B.; Zhao, Z.; Li, X. LADM-based modeling of the unified registration of immovable property in China. Land Use Policy 2017, 64, 292-306. [CrossRef]

24. Williamson, I.P. Land Administration for Sustainable Development; ESRI Press Academic: Redlands, CA, USA, 2010.

25. Guo, R.Z.; Li, L.; Ying, S.; Luo, P.; He, B.; Jiang, R. Developing a 3D cadastre for the administration of urban land use: A case study of Shenzhen, China. Comput. Environ. Urban Syst. 2013, 40, 46-55. [CrossRef]

26. Wu, C.B.; Ding, Y.; Zhou, X.X. Three-dimensional data modeling of real estate objects in China. J. Geogr. Sci. 2019, 21, 433-450.

27. Zulkifli, N.A.; Abdul Rahman, A.; Van Oosterom, P.J.M.; Tan, L.C.; Jamil, H.; Teng, C.H.; Looi, K.S.; Chan, K.L. The importance of Malaysian land administration domain model country profile in land policy. Land Use Policy 2015, 49, 649-659. [CrossRef]

28. Ying, S.; Guo, R.Z.; Li, L.; Van Oosterom, P.J.M.; Ledoux, H.; Stoter, J. Construction of 3D volumetric objects for a 3D cadastral system. Trans. GIS 2015, 19, 758-779. [CrossRef]

29. Ying, S.; Guo, R.Z.; Yang, J.; He, B.; Zhao, Z.; Jin, F. 3D space shift from city GML LoD3-based multiple building elements to a 3D volumetric object. ISPRS Int. J. Geoinform. 2017, 6, 17. [CrossRef]

30. Ying, S.; Li, L.; Guo, R.Z. Building 3D cadastral system based on 2D survey plans with SketchUp. Geospat. Inf. Sci. 2011, 14, 129-136. [CrossRef] 
31. Zardiny, A.Z.; Hakimpour, F. 3D web services for visualization and data sharing in 3D cadastre. Int. J. 3-D Inf. Model. 2015, 4, 1-15. [CrossRef]

32. Zhuo, Y.; Ma, Z.; Lemmen, C.; Bennett, R.M. Application of LADM for the integration of land and housing information in China: The legal dimension. Land Use Policy 2015, 49, 634-648. [CrossRef]

33. Ying, S.; Guo, R.Z.; Li, L.; Van Oosterom, P.J.M.; Ledoux, H.; Stoter, J. Design and development of a 3D cadastral system prototype based on the LADM and 3D topology. In Proceedings of the 2nd International Workshop on 3D Cadastres, Delft, The Netherlands, 16-18 November 2011.

34. Yu, C.B. Geometrical Representation, Construction and Visualization of 3D Natural Resource. Ph.D. Thesis, Wuhan University, Wuhan, China, 2015. 